\title{
Sequential bilateral testicular tumours presenting with intervals of 20 years and more
}

\author{
Klaus-Peter Dieckmann ${ }^{1 *}$, Petra Anheuser ${ }^{1}$, Florentine Sattler ${ }^{2}$, Tobias Von Kügelgen ${ }^{3}$, Cord Matthies ${ }^{4}$ \\ and Christian Ruf 4
}

\begin{abstract}
Background: About 3 - 5\% of all patients with testicular germ cell tumour (GCT) develop a contralateral cancer, the majority of which arise within 10-15 years. Little is known about the risk of second GCTs after more than two decades. Here we present 3 cases with very late presenting contralateral GCT and provide a summary of similar cases reported previously.
\end{abstract}

Case presentations: (1) This white Caucasian man underwent right-sided orchiectomy for a nonseminomatous GCT at the age of 22 years. Additional treatment consisted of retroperitoneal lymph node dissection (RPLND) and chemotherapy with 4 cycles of vinblastin / bleomycin. 36 years later, contralateral seminoma clinical stage 1 developed. Cure was achieved by orchiectomy. Histologically, testicular intraepithelial neoplasia (TIN; intratubular germ cell neoplasia) was detected in the tumour-surrounding tissue.

(2) This white Caucasian male had right-sided orchiectomy for nonseminomatous GCT at the age of 29 years. Pathological stage 1 was confirmed by RPLND. 25 years later, he received left sided orchiectomy for seminoma stage 1. Histologically, TIN was found in the tissue adjacent to seminoma. Two brothers had testicular GCT, too, one with bilateral GCT. (3) This 21 year old white Caucasian man underwent left-sided orchiectomy for nonseminomatous GCT. Pathological stage 1 was confirmed by RPLND. 21 years later, he received organ-preserving excision of a right-sided seminoma, followed by BEP chemotherapy for stage 3 disease. Histologically, TIN was found in the surrounding testicular tissue.

22 cases of bilateral GCT with intervals of 20 or more years have previously been reported, thereof three with intervals of more than 30 years, the longest interval being 40 years.

Conclusion: Apart from increased risks of cardiovascular diseases and non-testicular malignancies, patients with GCT face the specific probability of a second GCT in the long run. This risk persists life-long and is not eliminated by chemotherapy. Contralateral testicular biopsy can identify patients at risk by revealing precursor cells of GCT though false-negative biopsies may occur sporadically. However, in view of the multi-facetted late hazards of GCT patients, this minor surgical procedure might somewhat simplify the long-time care of these patients.

Keywords: Testicular germ cell neoplasms, Bilateral tumours, Testicular biopsy, Seminoma, Familial germ cell tumours

\section{Background}

The phenomenon of malignant growths occurring in both of the testicles has been known for more than a century. Hamilton and Gilbert conducted the first systematic review in 1942. Based on 144 cases collected from the literature they opened their milestone article with the sentence: "Testicular tumors possess a pronounced tendency to

\footnotetext{
* Correspondence: DieckmannKP@t-online.de

${ }^{1}$ Klinik für Urologie, Albertinen-Krankenhaus Hamburg, Suentelstr. 11a,

D-22457 Hamburg, Germany

Full list of author information is available at the end of the article
}

bilateralism" [1]. According to recent reviews, $3-5 \%$ of patients with testicular germ cell tumour (GCT) develop contralateral cancer which corresponds to a 20-30 fold increased relative risk of tumour [2-4]. About $50 \%$ of these events occur within 5 years after diagnosis of the primary while $90 \%$ do so within a 10 years time-span [5]. Only few more cancers arise thereafter. So far, little is known about the risk of contralateral GCT after very long intervals of more than two decades. All GCTs are preceded by a common precursor named testicular intraepithelial neoplasia (TIN; also called intratubular germ cell neoplasia

\section{Biomed Central}


unspecified, ITGCNU) which is thought to be present in the testicle many years before the clinical manifestation of GCT [6,7]. To identify candidates for second GCTs, contralateral testicular biopsy at the time of orchiectomy of the primary is available [8,9]. However, physicians caring for patients with GCT have widely remained disinclined to this pro-active method of early detection of GCT [10]. Thus clinically, the risk of bilateral testicular tumour needs to be considered during follow-up of patients with GCT. Importantly, as this event may occur beyond the usual 5 -years time-span of oncological follow-up, extended observation time is required.

Here we present three cases with exceptionally late onset of second GCT and we provide a survey of the literature regarding the problem of very long intervals between metachronous bilateral testicular tumours.

\section{Case presentations Case \#1}

This Caucasian white male underwent right-sided orchiectomy for a nonseminomatous testicular GCT at the age of 22 years. History was uneventful; in particular there was neither history of undescended testis nor any prior familial events of testis cancer. Bulky retroperitoneal lymph-node metastases were resected by extended retroperitoneal lymph node dissection (RPLND) followed by four cycles of chemotherapy. As cisplatin was not yet available at that time (1976), the patient received treatment with the contemporary Samuels regimen consisting of vinblastin and bleomycin [11]. Possibly as a sequel of transfusion therapy during multi-modal treatment for GCT, a viral hepatitis B infection was diagnosed one year thereafter. This infection entered a chronic non-aggressive course and the patient stayed disease-free with respect to testicular cancer for 36 years.

At the age of 58 years, he sought urological advice for an increase of his prostate specific antigen (PSA) level to $1.5 \mathrm{ng} / \mathrm{ml}$. The patient reported no specific symptoms with regard to scrotal disorders. Upon physical examination a firm nodule of about $1 \mathrm{~cm}$ in diameter was detected in the left testicle. Serum tumour markers beta Human chorionic gonadotropin (beta HCG), alpha fetoprotein (AFP) and lactic dehydrogenase (LDH) were within normal limits. Scrotal ultrasonography (Figure 1) and magnetic resonance imaging (MRI) revealed a mass of $1.3 \mathrm{~cm}$ in diameter within the testicle. As the testicle was small and atrophic, left sided orchiectomy was performed and no attempt of testis-sparing surgery was made. Histological work-up disclosed pure seminoma with vascular invasion but no infiltration of the rete testis. In the seminiferous tubules surrounding the tumour abundant TIN was detected (Figure 2). No metastases were detected, so the patient was placed on a surveillance strategy according to clinical stage I disease. Testosterone substitution is

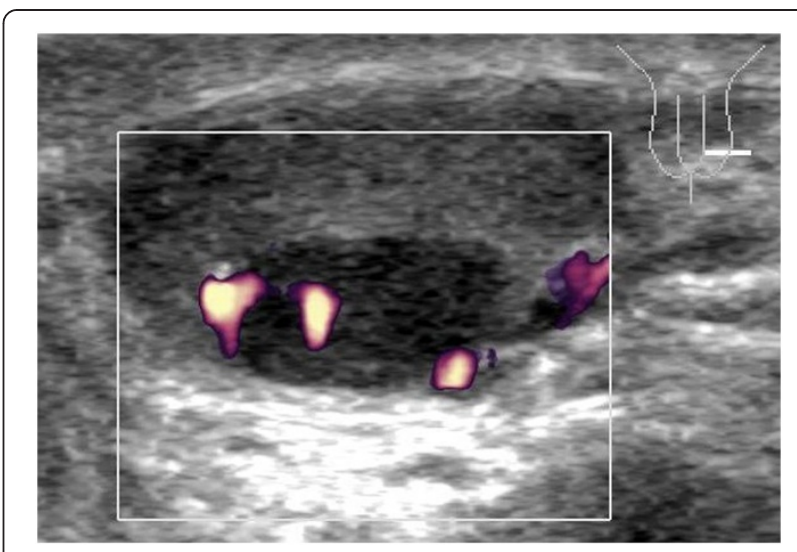

Figure 1 Grey scale ultrasonography of the testis with colour-coded duplex imaging. Note the hypo-echoic nodule at the cranial pole of the testis. Positive colour coded duplex signals indicate vascularisation of the tumour. Histologically, this tumour consisted of pure seminoma.

accomplished by periodic intramuscular injections. One year thereafter, the patient is well and without signs of tumour recurrence.

\section{Case \#2}

This white Caucasian man underwent right sided orchiectomy for a testicular teratocarcinoma at the age of 29 years. Pathological stage I was ascertained by RPLND. No further therapy was instituted. After 25 years when aged 54 years, the patient discovered a nodule in his remaining testicle by self-palpation. Imaging procedures including ultrasonography, elastography and MRI disclosed a $1.5 \mathrm{~cm}$ mass in the testicle. Serum tumour markers beta HCG, AFP and LDH were not increased. As preoperative hormone analysis had revealed a hypogonadal situation with subnormal testosterone level and increased luteinizing

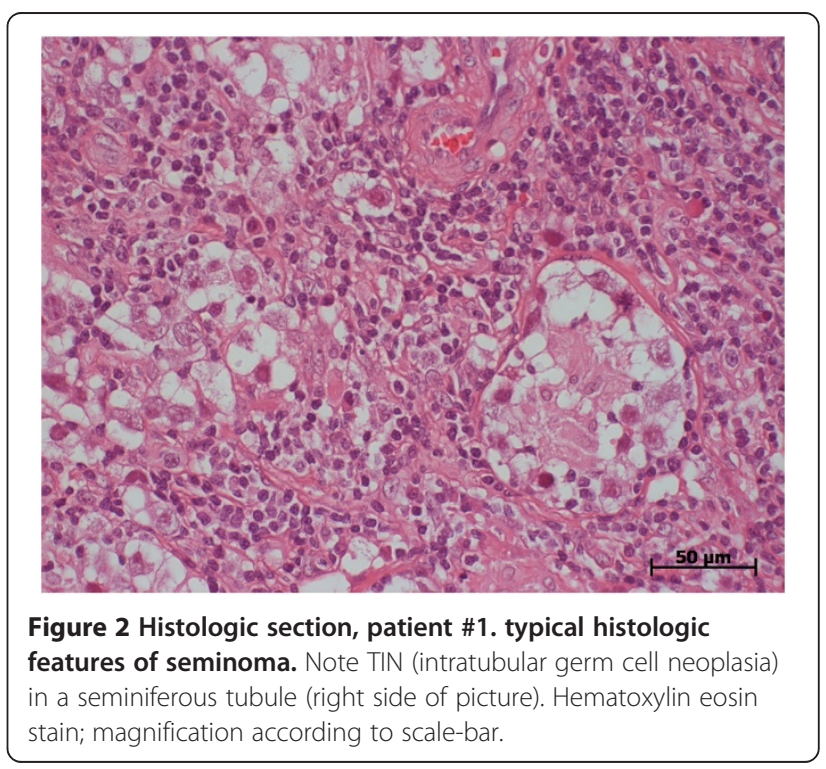


hormone (LH), no surgical attempts were made towards a testis-sparing procedure. Instead, a typical inguinal orchiectomy with insertion of a testicular prosthesis was carried out. Histologically, a classical seminoma was identified, with wide areas of TIN in the surrounding tissue. Chest and abdominal CT scans did not reveal metastases. No further treatment was instituted except for hormone replacement therapy. Follow-up of 12 months so far is uneventful. Family history is of particular note: The off-spring consists of one sister and six brothers, two of whom were also struck by testicular cancer. A younger brother succumbed to testicular choriocarcinoma at the age of 23 years. One older brother survived bilateral testicular cancer at ages 23 and 36 years.

\section{Case \#3}

This white Caucasian patient underwent left-sided orchiectomy along with a contralateral biopsy for a testicular teratocarcinoma at the age of 21 years. Histologically, the contralateral biopsy was without evidence of TIN. History was uneventful; in particular there was neither history of undescended testis nor any prior familial events of testis cancer. RPLND revealed pathological stage I. Thus, no systemic treatment was applied. At the age of 42 years, he presented with right-sided flank pain. Magnetic resonance imaging revealed dilatation of the right ureter caused by a huge retroperitoneal mass extending from the renal hilum into the pelvis. Beta HCG was slightly increased to $11.9 \mathrm{U} / \mathrm{l}$ (reference $<1.0 \mathrm{U} / \mathrm{l}$ ), as was LDH with $400 \mathrm{U} / \mathrm{l}$ (reference $<250 \mathrm{U} / \mathrm{l}$ ), while AFP was within normal limits. Scrotal ultrasonography revealed a mass of $1.9 \mathrm{~cm}$ in diameter in the testicle. Organ preserving surgery was performed along with additional biopsies of the adjacent testicular parenchyma. Histological work-up revealed pure seminoma with abundant TIN in the surrounding tissue. Mediastinal lymphadenopathy in addition to retroperitoneal metastases indicated stage III disease with good prognosis according to IGCCCG. The patient was rendered disease-free by systemic therapy with three cycles of cisplatin, etoposide and bleomycin (BEP). Two years thereafter, the patient is relapse-free and well.

\section{Conclusions}

There are at least four lessons to be learnt from these three cases:

(1) The risk of second (contralateral) cancer in GCT patients is pending life-long.

(2)Chemotherapy does not prevent a second testicular tumour.

(3) Familial clustering of testicular cancer appears to be associated with bilateral disease.

(4) Second tumours may arise despite a contralateral biopsy negative for TIN.
According to the most recent review, about $50 \%$ of all contralateral testicular tumours arise later than 5 years or more after the primary [2]. In a French analysis, 23\% of second tumours occurred between the $10^{\text {th }}$ and the $20^{\text {th }}$ year of follow-up [12], while no case developed later. All of the major investigations on bilateral testicular tumours accord with the contention, that the risk is high during the first ten years and that it is gradually decreasing thereafter forming an asymptotical curve approaching the zero line of risk beyond the 20 years mark [5,13-15]. As a matter of fact, this understanding implicates the sporadic occurrence of such tumours at exceptionally late time points. Accordingly, Table 1 provides a synopsis of 25 cases of the literature (including the present cases) with bilateral testicular germ cell tumours occurring after 20 or more years [1,3,12-14,16-32]. It is of note that already Hamilton and Gilbert in their 1942

Table 1 Sequential bilateral testicular germ-cell tumours with interval of $\mathbf{2 0}$ years or more

\begin{tabular}{|c|c|c|c|c|c|}
\hline Interval & $\begin{array}{l}\text { Age at first } \\
\text { presentation } \\
\text { (years) }\end{array}$ & $\begin{array}{l}\text { Histology } \\
\text { first tumour }\end{array}$ & $\begin{array}{l}\text { Second } \\
\text { tumour }\end{array}$ & $\begin{array}{l}\text { Reference, } \\
\text { first author, }\end{array}$ & Year \\
\hline 40 yrs & 40 & $S$ & $S$ & Philipsen [16] & 1994 \\
\hline 36 yrs & 22 & NS & $S$ & Present case I & 2013 \\
\hline 32 yrs & 26 & S & NS & Scheiber [17] & 1987 \\
\hline 31 yrs & 31 & n.a. & $\mathrm{S}$ & Fukuhara [18] & 2005 \\
\hline 29 yrs & 32 & NS & S & Manny [19] & 1999 \\
\hline $28 \mathrm{yrs}$ & n.a. & NS & n.a. & Andreassen [13] & 2011 \\
\hline $26 \mathrm{yrs}$ & 35 & NS & NS & Hoekstra [20] & 1982 \\
\hline $25 \mathrm{yrs}$ & 46 & n.a. & S & Melicow [21] & 1955 \\
\hline 25 yrs & 25 & $S$ & S & Aristizabal [22] & 1978 \\
\hline $25 \mathrm{yrs}$ & 42 & S & S & Ohyama [23] & 2002 \\
\hline $25 \mathrm{yrs}$ & 29 & NS & $\mathrm{S}$ & Klatte [24] & 2008 \\
\hline $25 \mathrm{yrs}$ & 25 & NS & S & Present case II & 2013 \\
\hline 24 yrs & n.a. & n.a. & n.a. & Schaapveld [3] & 2012 \\
\hline $23 \mathrm{yrs}$ & n.a. & $\mathrm{S}^{*}$ & $S^{*}$ & Hamilton [1] & 1942 \\
\hline 23 yrs & 23 & S & S & Kratzik [14] & 1991 \\
\hline $22 \mathrm{yrs}$ & n.a. & S & S & Fergusson [25] & 1962 \\
\hline 22 yrs & 32 & S & S & Yoshida [26] & 1981 \\
\hline $22 \mathrm{yrs}$ & 22 & n.a. & NS & Bach [27] & 1983 \\
\hline 22 yrs & 39 & $S$ & $\mathrm{~S}$ & Celebi [28] & 1995 \\
\hline 22 yrs & n.a. & n.a. & n.a. & Albers [29] & 1999 \\
\hline $21 \mathrm{yrs}$ & 17 & $S$ & S & Tekin [30] & 2000 \\
\hline 21 yrs & 21 & NS & S & Present case III & 2013 \\
\hline $20 \mathrm{yrs}$ & n.a. & NS & S & Oesterlind [31] & 1987 \\
\hline 20 yrs & 28 & NS & S & Dieckmann [32] & 1989 \\
\hline 20 yrs & n.a. & n.a. & n.a. & Theodore [12] & 2004 \\
\hline
\end{tabular}

S seminoma; NS nonseminoma; n.a. not available. *most probable histology, assumed from text. 
review briefly mentioned such a case [1], and Melicow in a scholarly review on testicular new growths did so in 1955 [21]. The longest interval ever reported is 40 years in a Danish man [16]. The present case (\#1) is ranking second on this list with an interval of 36 years.

The median age at primary presentation of the patients with very late presenting contralateral testicular tumour is 28.5 years that is not at variance with the over-all median age of patients with germ cell cancer [33]. Yet, there appears to be a slight deviation from the contention that patients with bilateral tumours usually experience a rather early presentation of their primary [12,34,35]. All of our cases had a nonseminomatous histology at first presentation which is somehow at variance with the preponderance of seminoma usually encountered in cases with bilateral testicular GCT [36]. Table 1 does not suggest any association of histology with the particular risk of late second GCT. Little is known about clinical stage at primary diagnosis and during relapse for these particular patients. In most of the reports (Table 1 ) information on clinical staging is not provided. In our series, only one had metastasized disease at primary presentation while two had stage I disease. So, the basic message of this compilation of cases is the information that the risk of contralateral testicular cancer will persist life-long.

(2) Our first case experienced his second tumour despite interval chemotherapy. Pathogenetically, all GCTs are preceded by the premalignant lesion TIN (ITGCNU) that is believed to be present in the contralateral testicle already at the time of the first tumour. Concerns regarding the low sensitivity of chemotherapy to eradicate the precursor in the contralateral gonad had been raised already in the 1980ies [37]. Accordingly, large series of patients with bilateral testicular tumours clearly revealed that chemotherapy does not protect against second tumours $[4,15]$. In the largest investigation of bilateral tumours performed on the SEER data base, 39 second tumours (> 1\%) were found among 3157 nonseminoma patients receiving chemotherapy [35]. Recently, it was shown that low doses of two cycles of cisplatin-based chemotherapy are probably without any considerable effect on TIN, three or more cycles may eradicate it in about $75 \%$ of cases [38]. Our patient had received 4 cycles of chemotherapy, however, that treatment did not involve cisplatin, which clearly is the most efficacious drug. So, one might speculate that the vinblastin/bleomycin regimen could have suppressed TIN only temporarily . Accordingly, it took 36 years for the remaining TIN cells to recover and to finally progress to invasive seminoma. In fact, there is some indication of extended intervals in bilateral GCTs following chemotherapy [13,15]. Our patient apparently represents the case with the longest lag time between sequential bilateral testicular tumours and interval chemotherapy. So, this case represents an exceptional example showing the low efficacy of chemotherapy to prevent sequential testicular neoplasms.

(3) Two brothers of case \#2 had suffered from testicular cancer, too, one of whom had even bilateral disease. Approximately 1-3\% of all patients with testicular GCT have close relatives with the same diagnosis [34]. Notably, 6-15\% of all familial cases of GCT develop bilateral disease while second GCTs occur in only 3-5\% among sporadic cases [39]. Accordingly, a strong hereditary predisposition of testicular GCT is assumed [40]. While the clinical evidence for the involvement of genetic factors in the etiology of GCT is undisputed, the assumed Testicular GCT 1 gene has so far not been identified [41]. From a practical point of view, it is concluded that history of familial testicular cancer should increase the clinician's vigilance regarding the possible development of contralateral cancer. As elucidated by the case, this event may even occur after a very long lag time.

(4) In one of our patients (\#3), contralateral GCT developed despite a previous testicular biopsy negative for TIN. False-negative biopsies do occur in less than $10 \%$ of cases [8]. Multiple probing has been recommended to reduce the rate of biopsy-failures. In fact, systematic two-site biopsies revealed an $18 \%$ extra yield of contralateral TIN [8]. Whether or not double biopsy would have disclosed the true diagnosis at that time remains elusive, but clearly, multiple biopsies are more sensitive than a single one.

Our three cases highlight one of the manifold problems in the long-time follow-up of patients with testicular GCT. The specific risk of a second testicular tumour is one threat in addition to the well-recognized hazards of metabolic disorders, cardiovascular diseases and non-testicular malignancies [42]. The risk of contralateral GCT is not eliminated by chemotherapy. As all of our patients had TIN in the tumour-surrounding tissue, histologically, a contralateral biopsy at the time of the primary might have identified the impending second tumour. Although not explicitly recommended by current guide-lines [43-45], contralateral testicular biopsy is clearly valuable for exploring the particular risk of second testicular cancer $[8,46]$.

\section{Consent}

Written informed consent was obtained from all of the three patients for publication of these Case reports and the two accompanying images. A copy of the written consent is available for review by the Editor of this journal.

\section{Competing interests \\ The authors declare that they have no competing interests.}

\section{Authors' contributions}

KPD conceived and designed the study, analyzed the clinical data, and drafted the manuscript. PA performed the ultrasonographic examinations of the patients, participated in the clinical management of cases, participated in designing and of the report and drafting of the manuscript. FS carried out the histological examinations, participated in designing the report. TK 
participated in the designing of the study, carried out much of the clinical management of the cases, helped analyzing the clinical data. CM participated in the designing of the study, accumulated and abstracted the clinical data, helped in clinical management of the cases. CR conceived the study, participated in designing the report, analyzed the clinical data, and drafted the manuscript. All authors read and approved the final manuscript.

\section{Acknowledgement}

This study was supported by the German Ministry of Defence.

\section{Author details}

'Klinik für Urologie, Albertinen-Krankenhaus Hamburg, Suentelstr. 11a, D-22457 Hamburg, Germany. ${ }^{2}$ Institut für Hämatopathologie, Fangdieckstrasse 75a, D-22547 Hamburg, Germany. ${ }^{3}$ Praxis für Urologie, Rosengarten 5, D-22880 Wedel, Holstein, Germany. ${ }^{4}$ Bundeswehrkrankenhaus Hamburg, Abteilung für Urologie, Lesserstrasse 180, D-22049 Hamburg, Germany.

Received: 7 July 2013 Accepted: 4 December 2013

Published: 9 December 2013

\section{References}

1. Hamilton JB, Gilbert JB: Studies in malignant tumors of the testis. IV. Bilateral testicular cancer. Incidence, nature, and bearing upon management of the patient with a single testicular cancer. Cancer Res 1942, 2:125-129.

2. Zequi SD, da Costa WH, Santana TB, Favaretto RL, Sacomani CA, Guimaraes GC: Bilateral testicular germ cell tumours: a systematic review. BJU Int 2012, 110(8):1102-1109.

3. Schaapveld M, van den Belt-Dusebout AW, Gietema JA, de Wit R, Horenblas S, Witjes JA, Hoekstra HJ, Kiemeney LA, Louwman WJ, Ouwens GM, et al: Risk and prognostic significance of metachronous contralateral testicular germ cell tumours. Br J Cancer 2012, 107(9):1637-1643.

4. Hoff Wanderas E, Fossa SD, Tretli S: Risk of a second germ cell cancer after treatment of a primary germ cell cancer in 2201 Norwegian male patients. Eur J Cancer 1997, 33(2):244-252.

5. Dieckmann KP, Boeckmann W, Brosig W, Jonas D, Bauer HW: Bilateral testicular germ cell tumors, Report of nine cases and review of the literature. Cancer 1986, 57(6):1254-1258.

6. Hoei-Hansen CE, Rajpert-De Meyts E, Daugaard G, Skakkebaek NE: Carcinoma in situ testis, the progenitor of testicular germ cell tumours: a clinical review. Ann Oncol 2005, 16:863-868.

7. Dieckmann KP, Loy V, Huland H: Das Carcinoma in situ des Hodens: klinische Bedeutung, Diagnose und Therapie. Urologe A 1989, 28:271-280.

8. Dieckmann KP, Kulejewski M, Heinemann V, Loy V: Testicular biopsy for early cancer detection - objectives, technique and controversies. Int J Androl 2011, 34(4 Pt 2):e7-e13.

9. Dohle GR, Elzanaty $\mathrm{S}$, van Casteren NJ: Testicular biopsy: clinical practice and interpretation. Asian J Androl 2012, 14(1):88-93.

10. Beyer J, Albers P, Altena R, Aparicio J, Bokemeyer C, Busch J, Cathomas R, Cavallin-Stahl E, Clarke NW, Claßen J, et al: Maintaining success, reducing treatment burden, focusing on survivorship: highlights from the third European consensus conference on diagnosis and treatment of germ-cell cancer. Ann Oncol 2012, 24(4):878-888.

11. Samuels ML, Lanzotti VJ, Holoye PY, Boyle LE, Smith TL, Johnson DE: Combination chemotherapy in germinal cell tumors. Cancer Treat Rev 1976, 3(4):185-204

12. Theodore C, Terrier-Lacombe MJ, Laplanche A, Benoit G, Fizazi K, Stamerra $\mathrm{O}$, Wibault $\mathrm{P}$ : Bilateral germ-cell tumours: 22-year experience at the Institut Gustave Roussy. Br J Cancer 2004, 90:55-59.

13. Andreassen KE, Grotmol T, Cvancarova MS, Johannesen TB, Fossa SD: Risk of metachronous contralateral testicular germ cell tumors: a population-based study of 7,102 Norwegian patients (1953-2007). Int J Cancer 2011, 129(12):2867-2874.

14. Kratzik C, Aiginger P, Kuber W, Riccabona M, Kuhrer I, Joos H, Frick J, Amann G, Mayr W: Risk factors for bilateral testicular germ cell tumors. Does heredity play a role? Cancer 1991, 68(4):916-921.

15. Geczi L, Gomez F, Bak M, Bodrogi I: The incidence, prognosis, clinical and histological characteristics, treatment, and outcome of patients with bilateral germ cell testicular cancer in Hungary. $J$ Cancer Res Clin Oncol 2003, 129:309-315.
16. Philipsen JP, Gimbel HM: Cancer of the testis in an 80 year old man with a former contralateral testicular cancer. (in Danish). Ugeskr Laeger 1994, 156:2908-2909.

17. Scheiber K, Ackermann D, Studer UE: Bilateral testicular germ cell tumors: a report of 20 cases. J Urol 1987, 138:73-76.

18. Fukuhara $Y$, Shiga $Y$, Ken S: [Bilateral testicular tumors recurring 31 years after the initial treatment: a case report and the literature review][Article in Japanese]. Nippon Hinyokika Gakkai Zasshi 2005, 96:17-20.

19. Manny HP, Thon WF, Brüschke C, Ostertag H: Spätes Auftreten eines metachronen bilateralen Hodentumors und eines keimzellunabhängigen Zweittumors. Akt Urol 1999, 30:422-425.

20. Hoekstra HJ, Wobbes T, Sleyfer DT, Schraffordt Koops H: Bilateral primary germ cell tumors of testis. Urology 1982, 19(2):152-154.

21. Melicow MM: Classification of tumors of testis: a clinical and pathological study based on 105 primary and 13 secondary cases in adults, and 3 primary and 4 secondary cases in children. J Urol 1955, 73(3):547-574

22. Aristizabal S, Davis JR, Miller RC, Moore MJ, Boone ML: Bilateral primary germ cell testicular tumors: report of four cases and review of the literature. Cancer 1978, 42(2):591-597.

23. Ohyama C, Kyan A, Satoh M, Saito S, Nishimura Y, Imai Y, Oikawa K, Yokoyama J, Suzuki K, Takeuchi M, et al: Bilateral testicular tumors: a report of nine cases with long-term follow-up. Int I Urol 2002, 9(3):173-177.

24. Klatte T, de Martino M, Arensmeier K, Reiher F, Allhoff EP, Klatte D: Management and outcome of bilateral testicular germ cell tumors: a 25-year single center experience. Int J Urol 2008, 15(9):821-826.

25. Fergusson JD: Tumours of the testis. Brit J Urol 1962, 34:407-421.

26. Yoshida M, Machida T, Masuda F, Miki M, Ohishi Y, Ueda M, Yanagisawa M, Tanino M, Kishimoto K, Kawaguchi Y: [Five cases of bilateral testicular tumors: a review of 118 cases in Japanese literature (author's transl)]. [Article in Japanese]. Nihon Hinyokika Gakkai Zasshi 1981, 72(4):460-472.

27. Bach DW, Weissbach L, Hartlapp JH: Bilateral testicular tumor. J Urol 1983, 129(5):989-991.

28. Celebi I, Tekgül S, Ozen HA, Ozgü I, Remzi D: Sequential bilateral germ cell tumours of the testis. Int Urol Nephrol 1995, 27(2):183-187.

29. Albers P, Goll A, Bierhoff E, Schoeneich G, Müller SC: Clinical course and histopathologic risk factor assessment in patients with bilateral testicular germ cell tumors. Urology 1999, 54:714-718.

30. Tekin A, Aygun YC, Aki FT, Ozen H: Bilateral germ cell cancer of the testis: a report of 11 patients with a long-term follow-up. BJU Int 2000, 85:864-868.

31. Osterlind A, Berthelsen JG, Abildgaard N, Hansen SO, Hjalgrim H, Johansen B, Munck Hansen J, Rasmussen LH: Risk of bilateral testicular germ cell cancer in Denmark: 1960-1984. J Natl Cancer Inst 1991, 83(19):1391-1395.

32. Dieckmann KP, Düe W, Klän R: Bilateraler Hodentumor nach Intervall von 20 Jahren. Med Welt 1989, 40:75-76.

33. Ruf CG, Isbarn H, Wagner W, Fisch M, Matthies C, Dieckmann KP: Changes in epidemiologic features of testicular germ cell cancer: age at diagnosis and relative frequency of seminoma are constantly and significantly increasing. Urol Oncol 2013. doi: 10.1016/j.urolonc.2012.12.002. [Epub ahead of print].

34. Nicholson PW, Harland SJ: Inheritance and testicular cancer. Br J Cancer 1995, 71:421-426.

35. Fossa SD, Chen J, Schonfeld SJ, McGlynn KA, McMaster ML, Gail MH, Travis LB: Risk of contralateral testicular cancer: a population-based study of 29,515 U.S. men. J Natl Cancer Inst 2005, 97:1056-1066.

36. Thomas JP, Davis-Dao C, Lewinger JP, Siegmund KD, Hamilton AS, Daneshmand S, Skinner EC, Thomas DC, Cortessis VK: Null association between histology of first and second primary malignancies in men with bilateral testicular germ cell tumors. Am J Epidemiol 2013, 178(8):1240-1245.

37. Bottomley D, Fisher C, Hendry WF, Horwich A: Persistent carcinoma in situ of the testis after chemotherapy for advanced testicular germ cell tumours. Br J Urol 1990, 66(4):420-424.

38. Dieckmann KP, Wilken S, Loy V, Matthies C, Kleinschmidt K, Bedke J, Martinschek A, Souchon R, Pichlmeier U, Kliesch S: Treatment of testicular testicular neoplasia (intratubular germ cell neoplasia unspecified) with local radiotherapy or with platinum-based chemotherapy: a survey of the German Testicular Cancer Study Group. Ann Oncol 2013, 24(5):1332-1337.

39. Mai PL, Friedlander M, Tucker K, Phillips KA, Hogg D, Jewett MA, Lohynska R, Daugaard G, Richard S, Bonaïti-Pellié C, The International Testicular Cancer 
Linkage Consortium, et al: A clinicopathologic descriptive analysis of 461 familial malignant testicular germ cell tumor kindred. Urol Oncol 2010 28(5):492-499.

40. Hemminki K, Li X: Familial risk in testicular cancer as a clue to a heritable and environmental aetiology. Br J Cancer 2004, 90:1765-1770.

41. Kratz CP, Mai PL, Greene MH: Familial testicular germ cell tumours. Best Pract Res Clin Endocrinol Metab 2010, 24(3):503-513.

42. Abouassaly R, Fossa SD, Giwercman A, Kollmannsberger C, Motzer RJ, Schmoll HJ, Sternberg CN: Sequelae of treatment in long-term survivors of testis cancer. Eur Urol 2011, 60(3):516-526.

43. Albers P, Albrecht W, Algaba F, Bokemeyer C, Cohn-Cedermark G, Fizazi K, Horwich A, Laguna MP: EAU guidelines on testicular cancer: 2011 update. Eur Urol 2011, 60(2):304-319.

44. Motzer RJ, Agarwal N, Beard C, Bhayani S, Bolger GB, Buyyounouski MK, Carducci MA, Chang SS, Choueiri TK, Gupta S, et al: Testicular cancer. J Natl Compr Canc Netw 2012, 10(4):502-535.

45. Howard GC, Nairn M, on behalf of the Guideline Development Group: Management of adult testicular germ cell tumours: summary of updated SIGN guideline. BMJ 2011, 342:d2005.

46. Rud CN, Daugaard G, Rajpert-De Meyts E, Skakkebæk NE, Petersen JH, Jørgensen N: Sperm concentration, testicular volume and age predict risk of carcinoma-in-situ in contralateral testis of men with testicular germ-cell cancer. J Urol 2013, 190(6):2074-2080.

doi:10.1186/1471-2490-13-71

Cite this article as: Dieckmann et al:: Sequential bilateral testicular tumours presenting with intervals of 20 years and more. BMC Urology 2013 13:71.

\section{Submit your next manuscript to BioMed Central and take full advantage of:}

- Convenient online submission

- Thorough peer review

- No space constraints or color figure charges

- Immediate publication on acceptance

- Inclusion in PubMed, CAS, Scopus and Google Scholar

- Research which is freely available for redistribution 